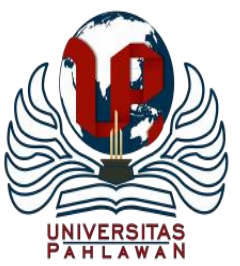

JURNAL BASICEDU

\author{
Volume 5 Nomor 3 Tahun 2021 Halaman 1689-1694 \\ Research \& Learning in Elementary Education \\ https://jbasic.org/index.php/basicedu
}

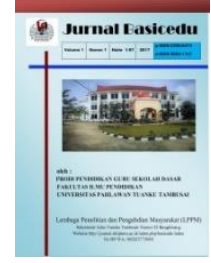

\title{
Dampak Pandemi Covid-19 terhadap Pembelajaran Tematik di Sekolah Dasar
}

\author{
Rizki Ananda $^{1 凶}$, Fadhilaturrahmi $^{2}$, Imam Hanafi ${ }^{3}$ \\ (Program Studi Pendidikan Guru Sekolah Dasar, Universitas Pahlawan Tuanku Tambusai ${ }^{1,2}$ ) \\ rizkiananda@universitaspahlawan.ac.id ${ }^{1}$, fadhilaturrahmi@universitaspahlawan.ac.id ${ }^{2}$, \\ imamhanafimpd91@gmail.com ${ }^{3}$
}

\begin{abstract}
Abstrak
Tujuan dari penelitian ini adalah untuk mengidentifikasi serta mendapatkan informasi mengenai dampak dari pandemi Covid-19 terhadap proses pembelajaran tematik di Sekolah Dasar. Penelitian ini menggunakan pendekatan deskriptif kualitatif dengan metode studi kasus. Setting penelitian dilaksanakan di SDN Kecamatan Bangkinang Kota. Adapun yang menjadi subjek penelitian diantaranya guru, siswa, dan orang tua siswa dengan cara mengamati serta melakukan wawancara terhadap pelaksanaan pembelajaran daring selama pandemi COVID-19. Tahapan dari penelitian ini mengikuti prosedur penelitian kualitatif seperti pengumpulan data, reduksi data, penyajian data, dan penarikan kesimpulan. Hasil penelitian mengungkapkan bahwa keterlaksanaan pembelajaran tematik tidak dapat dilakukan secara ideal seperti saat situasi normal/ sebelum pandemi Covid-19 terjadi. Pembelajaran lebih banyak dilaksanakan secara terpisah (separated) dan bukan terintegrasi antar mata pelajaran seperti seharusnya pembelajaran tematik integratif dilaksanakan. Sementara itu dari 4 kompetensi siswa yang seharusnya menjadi capaian pembelajaran pada pembelajaran tematik kompetensi yang dapat dilaksanakan dan tercapai maksimal adalah kompetensi pengetahuan. Hasil dari penelitian ini diharapkan dapat memberikan rekomendasi bagi penyelanggara pendidikan dan seluruh stakeholders pendidikan agar proses pendidikan tetap bisa berlangsung dalam kondisi apapun.
\end{abstract}

Kata Kunci: pandemi COVID-19, pembelajaran tematik, sekolah dasar.

\begin{abstract}
The purpose of this study is to identify and obtain information about the impact of the Covid-19 pandemic on the thematic learning process in elementary schools. This research uses a qualitative descriptive approach with a case study method. The setting of the research was carried out at SDN Bangkinang Kota District. The research subjects included teachers, students, and parents of students by observing and conducting interviews on the implementation of online learning during the COVID19 pandemic. The stages of this research follow qualitative research procedures such as data collection, data reduction, data presentation, and drawing conclusions. The results of the study reveal that the implementation of thematic learning cannot be carried out ideally as in normal situations / before the Covid-19 pandemic occurred. More learning is carried out separately and not integrated between subjects as how integrative thematic learning should be carried out. Meanwhile, of the 4 student competencies that should be learning outcomes in thematic learning, the competencies that can be implemented and achieved maximally are knowledge competencies. The results of this study are expected to provide recommendations for education providers and all education stakeholders so that the educational process can continue under any conditions.
\end{abstract}

Keywords: COVID-19 pandemic, thematic learning, elementary school.

Copyright (c) 2021 Rizki Ananda $^{1}$, Fadhilaturrahmi $^{2}$, Imam Hanafi $^{3}$

Corresponding author :

Email : rizkiananda@universitaspahlawan.ac.id

DOI: https://doi.org/10.31004/basicedu.v5i3.1190

ISSN 2580-3735 (Media Cetak)

ISSN 2580-1147 (Media Online) 
1690 Dampak Pandemi COVID-19 terhadap Pembelajaran Tematik di Sekolah Dasar - Rizki Ananda,

Fadhilaturrahmi, Imam Hanafi

DOI: https://doi.org/10.31004/basicedu.v5i3.1190

\section{PENDAHULUAN}

Pendidikan adalah salah satu indikator utama dalam melihat maju mundurnya sebuah bangsa. Tanpa penyelenggaraan pendidikan yang berkualitas maka cita-cita untuk menjadi bangsa yang maju dan berperadaban hanyalah isapan jempol belaka. Secara gamblang bapak bangsa Vietnam membuat sebuah pernyataan sebagai tolak ukur fondasi pentingnya pendidikan yaitu "No Teacher, No Education, No Education, No Economic and Social Development (Luthfi, 2013)". Dari pernyataan tersebut dijelaskan secara tersurat bahwa tanpa ada pendidikan tidak akan mungkin ada perkembangan ekonomi dan sosial. Pendidikan pula memiliki tanggungjawab untuk mengembangkan karakter anak bangsa, karena salah satu tugas dari pendidikan yaitu untuk mewariskan nilai-nilai luhur bangsa dan para leluhur.

Berdasarkan kepada pandangan di atas, ada hal krusial yang harus diambil oleh para pelakasana pendidikan ditengah pandemi covid 19 yang sedang melanda dunia, khususnya Indonesia. Berdasarkan data dari Kemendikbud Tahun 2020 bahwa banyaknya siswa yang terdampak covid 19 sehingga mengharuskan mereka belajar di rumah yaitu sebanyak, Sekolah Dasar dan Sederajat sebanyak: 28,6 Juta, Sekolah Menengah Pertama dan Sederajat sebanyak: 13,1 Juta, Sekolah Menengah Atas dan Sederajat sebanyak: 11,3 Juta, dan Pendidikan Tinggi sebanyak: 6,3 Juta (Kemendikbud, 2020). Dari sekian banyak siswa yang terdampak tidak mungkin dibiarkan begitu saja, pembelajaran dan pendidikan harus tetap dilanjutkan walaupun ada berbagai kekurang dan keterbatasan yang harus dihadapi.

Pemerintah melalui Kementerian Pendidikan dan Kebudayaan sudah mengambil kebijakan dengan memberlakukan prinsip phisical distancing pada seluruh lapisan masyarakat, bahkan di beberapa kota besar di Indonesia diberlakukan pula PSBB (Pembatasan Sosial Berskala Besar) guna memutus rantai penyebaran virus ini. Kebijakan tersebut memberikan. dampak pada pendidikan di Indonesia khususnya pada proses pembelajaran bagi siswa sekolah. Penerapan phisical distancing pada jenjang sekolah dasar dan menengah terus dilaksanakan hingga kondisi dinyatakan kondusif. Selama pandemi berlangsung, sekolah memang diliburkan tetapi proses pembelajaran harus tetap berlangsung dengan menerapkan pola pembelajaran jarak jauh (PJJ). Selama pandemi berlangsung, kini pembelajaran dalam jaringan (daring) telah dilakukan di hampir seluruh dunia (Goldschmidt, 2020). Sehingga, pada pembelajaran daring ini, semua elemen pendidikan dituntut untuk tetap mampu memfasilitasi pembelajaran agar tetap aktif meskipun tanpa tatap muka secara langsung. Guru selaku elemen utama dalam pendidikan formal dipacu untuk melakukan adaptasi dengan pelaksanaan pembelajaran yang semula menggunakan metode tatap muka konvensional dan beralih ke pembelajaran daring.

Kekurangan dan keterbatasan yang harus dihadapi oleh guru diantanya yaitu: 1) guru tidak berpikiran secepat ini harus menggunakan pembelajaran secara daring, walaupun ada upaya ke arah tersebut, namun tidak terpikirkan akan secepat ini; 2) tidak semua guru memiliki keterampilan literasi digital yang sama, ada guru yang relative lebih mampu beradaptasi, namun ada pula yang tidak mampu beradaptasi, sehingga mereka mengalami kesulitan untuk pembelajaran secara daring; 3) tidak semua guru dan siswa memiliki perangkat minimal yang bisa digunakan, sehingga pembelajaran daring sulit untuk dilakukan; 4) Kualitas koneksi dan ketersedaan paket data yang masih terbatas, dan membutuhkan biaya yang besar, sehingga hal ini menjadi kendala. Belum lagi permasalahan pendekatan tematik integratif dengan penilaian autentiknya pada kurikulum 2013 yang pada kondisi normal saja sulit untuk dipahami dan dilaksanakan oleh guru apalagi dalam kondisi pembelajaran jarak jauh seperti saat ini.

Penelitian ini mencoba menggali informasi mengenai dampak pandemi Covid-19 terhadap pembelajaran tematik di sekolah dasar. Pada penelitian (Ananda \& Fadhilaturrahmi, 2018) sebelumnya telah mengkaji bagaimana kemampuan guru dalam mengimplementasikan pembelajaran tematik pada 
1691 Dampak Pandemi COVID-19 terhadap Pembelajaran Tematik di Sekolah Dasar - Rizki Ananda, Fadhilaturrahmi, Imam Hanafi

DOI: https://doi.org/10.31004/basicedu.v5i3.1190

saat situasi normal (sebelum pandemi Covid-19 terjadi). Lebih lanjut penelitian (Ananda, 2014) telah mengkaji seperti apa keterlaksanaan pembelajaran tematik dengan pendekatan saintifik dalam proses pembelajaran ketika belum memasuki era normal baru (new normal). Hal inilah yang membedakan dengan penelitian ini yang mencoba mengkaji apakah pembelajaran tematik di sekolah dasar bisa dilakukan dengan baik dan efektif, serta bagaimana ketecapaian kompetensi siswa selama pelaksanaan pembelajaran jarak jauh di masa pandemi Covid-19? Sehingga melalui dari hasil penelitian diharapkan dapat memberikan informasi dan pengetahuan bagi segenap insan pendidikan dalam merumuskan model pendidikan (pembelajaran) ideal saat pandemi Covid-19 dan pasca pandemi ini berakhir nantinya.

\section{METODE}

Pendekatan yang digunakan dalam penelitian ini adalah pendekatan kualitatif. penelitian ini dapat digolongkan ke dalam penelitian kualitatif-naturalistik. Penelitian kualitatif-naturalistik, peneliti memperlakukan dirinya sebagai instrument utama (human instrument) yaitu bergerak dari hal-hal yang spesifik, dan dari tahapan yang satu ke tahap berikutnya, serta memadukannya sedemikian rupa sehingga pada akhirnya dapat ditemukan kesimpulan-kesimpulan. Sejalan dengan itu, Creswell (2010:261) mengatakan bahwa dalam penelitian kualitatif peneliti adalah instrument kunci (researcher as key instrument) yang mengumpulkan sendiri data melalui dokumentasi, observasi dan wawancara dengan partisipan. Sebagai instrumen kunci peneliti dibantu oleh 3 (tiga) orang kolaborator dalam mengumpulkan data penelitian terutama yang berhubungan dengan pengamatan langsung di lapangan dengan menggunakan pedoman observasi dan pencatatatan lapangan. Data-data yang berhubungan dengan informan secara langsung peneliti sebagai intrumen kunci langsung melakukan sendiri wawancara kepada 6 orang guru di SDN 007 dan SDN 016 Bangkinang Kota.

Penelitian dilaksanakan selama 4 bulan (September-Desember) pada semester ganjil 2020-2021. Subjek dalam penelitian ini adalah guru, siswa, dan orang tua/wali murid dari SD tempat penelitian. Penelitian dibatasi terkait dengan proses pembelajaran selama masa pembelajaran jarak jauh, serta seluruh aktivitas guru dan siswa selama dalam proses pembelajaran jarak jauh. Tujuan pembatasan ini adalah agar kajian analisis dampak pandemi covid-19 terhadap pembelajaran tematik dapat dilakukan secara komprehensif dan mendalam.

Analisis data mengikuti cara Miles dan Huberman (Sugiyono, 2012) yang terdiri dari empat alur kegiatan, yaitu: pengumpulan data, reduksi data, display data, dan verifikasi/ menyimpulkan data. Untuk pengujian keabsahan temuan penelitian dilakukan dengan 1) Credibility (kredibilitas) dalam penelitian ini dimaksudkan untuk meningkatkan derajat kepercayaan. Kredibilitas ini dilakukan dengan cara: peneliti melakukan penelitian secara mendalam dengan jangka waktu yang relative panjang, yaitu dari bulan Agustus sampai bulan Desember 2020. Waktu ini digunakan untuk triangulasi, yaitu pemeriksaan keabsahan data dengan cara mengecek atau membandingkan data melalui pemanfaatan sumber-sumber lain, seperti peer debriefing (pembicaraan dengan kolega, termasuk pembicaraan dengan rekan kuliah satu angkatan yang tidak memiliki kepentingan dengan penelitian yang dilakukan peneliti), dan melakukan member-check dengan membawa kembali laporan akhir atau deskripsideskripsi atau tema-tema spesifik kehadapan partisipan untuk mengecek apakah mereka merasa bawa laporan/ deskripsi/ tema tersebut sudah akurat. 2) Transferability, peneliti mencoba mendeskripsikan informasi atau data penelitian secara luas dan mendalam tentang dampak pembelajaran jarak jauh di masa pandemi Covid-19 terhadap keterlaksanaan pembelajaran tematik. 3) Dependability, ini dilakukan dengan cara menggunakan catatan-catatan lapangan tentang seluruh proses dan hasil penelitian. 4) Confirmability, peneliti mendeteksi catatan-catatan di lapangan sehingga dapat ditelusuri kembali, peneliti juga dapat melakukan triangulasi dengan rekan sejawat dosen agar diperoleh analisis data yang akurat. 
1692 Dampak Pandemi COVID-19 terhadap Pembelajaran Tematik di Sekolah Dasar - Rizki Ananda, Fadhilaturrahmi, Imam Hanafi

DOI: https://doi.org/10.31004/basicedu.v5i3.1190

\section{HASIL DAN PEMBAHASAN}

\section{Keterlaksanaan Pembelajaraan Tematik Selama Pandemi Covid-19}

Data penelitian terkait keterlaksanaan pembelajaraan tematik di sekolah dasar selama pelaksanaan kebijakan pembelajaran jarak jauh pada SDN 016 Bangkinang Kota dan SDN 007 Bangkinang Kota peneliti peroleh dari hasil observasi sepanjang bulan September sampai dengan bulan Desember 2020 (sebelum penerimaan raport semester ganjil 2020-2021). Adapun dalam pengumpulan data ini peneliti dibantu oleh 3 orang mahasiswa PGSD yang melaksanakan Program Pengalaman Lapangan (PPL) dan satu orang orang dosen sejawat. Observer mengumpulkan data penelitian dengan menggunakan pedoman observasi.

Berdasarkan data hasil pengamatan oleh 3 orang observer diperoleh gambaran bahwa selama semester ganjil 2020-2021 siswa tidak dapat melaksanakan proses pembelajaran tatap muka di kelas. Siswa dan orang tua hanya datang sekali seminggu ke sekolah untuk menjemput tugas yang diberikan guru kelas sekaligus menyerahkan tugas yang sudah dikerjakan pada minggu sebelumnya. Tatap muka di kelas hanya dilakukan dalam rangka menjelaskan hal-hal terkait tugas untuk siswa yang tidak memahami tugas yang diberikan wali kelasnya. Kehadiran siswa dalam menanyakan tugas dibatasi maksimal 10 orang dalam satu kelas.

Terkait pelaskanaan proses pembelajaran selama semester ganjil 2020-2021 pada dua SD yang diteliti, sebagian besar pembelajaran dilaksanakan jarak jauh dengan metode online learning (dalam jaringan/ daring) dan offline learning (luar jaringan/ luring). Serta dengan mengkombinasikan pembelajaran daring dan luring (darling). Pada pembelajaran daring guru-guru sebagian besar menggunakan grup whatsapps dan google classroom sebagai media pembelajarannya.

Adapun keterlaksanaan pembelajaran tematik tidak dapat dilakukan secara ideal seperti saat situasi normal/ sebelum pandemi Covid-19 terjadi. Berdasarkan pengamatan observer, pembelajaran lebih banyak dilaksanakan secara terpisah (separated) dan bukan terintegrasi antar mata pelajaran seperti seharusnya pembelajaran tematik integratif dilaksanakan.

Hal ini tentu berbeda dengan yang dijelaskan (Mulyasa, 2013), (Prastowo, 2014) bahwa pemblajaran tematik semestinya dilakukan dengan mengintegrasikan beberapa mata pelajaran ke dalam satu tema tertentu. Hal ini tidak berlaku (tidak terlaksana) dalam situasi pembelejaran jarak jauh (PJJ) selama pandemi covid-19 berlangsung.

\section{Ketercapaian Kompetensi Siswa di Masa Pandemi Covid-19}

Berdasarkan data hasil penelitian yang diperoleh dari dokumen lembar kerja peserta didik tugas, hasil observasi, dan data hasil wawancara dengan guru SDN 007 Bangkinang Kota serta SDN 016 Bangkinang Kota, dapat dideskripsikan bahwa kompetensi siswa yang seharusnya meliputi Kompetensi Spiritual, Kompetensi Sosial, Kompetensi Pengetahuan, dan Kompetensi Keterampilan tidak semuanya tercapai dalam proses pembelajara di masa pandemi ini. Dari 4 kompetensi siswa yang seharusnya menjadi capaian pembelajaran pada pembelajaran tematik kompetensi yang dapat dilaksanakan dan tercapai maksimal adalah kompetensi pengetahuan. Hal ini dapat dilihat pada dokumen pembelajaran yang terdapat pada google classroom, WA Grup, dan tugas mingguan yang diberikan guru sebagian besarnya didominasi oleh penguasaan pengetahuan. 
1693 Dampak Pandemi COVID-19 terhadap Pembelajaran Tematik di Sekolah Dasar - Rizki Ananda, Fadhilaturrahmi, Imam Hanafi

DOI: https://doi.org/10.31004/basicedu.v5i3.1190

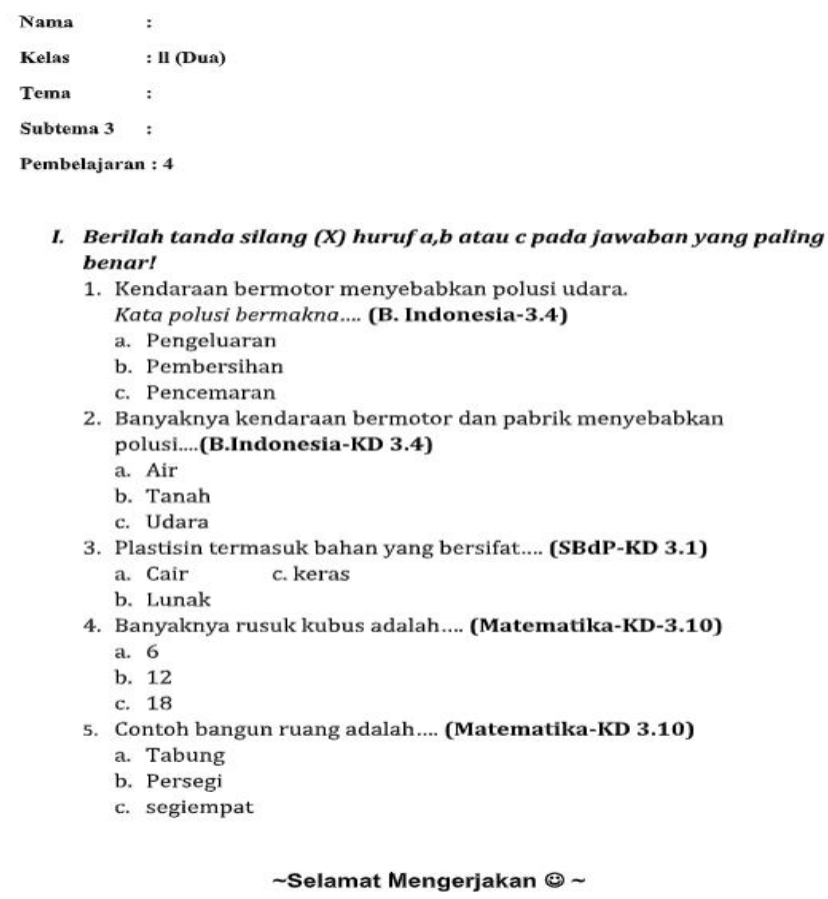

Gambar 1. Contoh tugas siswa yang dikirimkan melalui Google Classroom

Sementara itu, berdasarkan hasil wawancara dengan guru didapatkan informasi dari guru-guru pada dua sekolah yang diteliti bahwa sangat sulit untuk ketercapaian kompetensi siswa secara menyeluruh dan ideal dalam kondisi pandemi ini. Guru-guru juga menyampaikan bahwa untuk kompetensi spiritual, sosial, dan keterampilan hanya dapat tercapai maksimal dalam proses pembelajaran tatap muka di kelas. Hal ini tentu saja berbeda dengan hasil kajian Wildan, W. (2017) bahwa dalam melakukan penilaian dalam pembelajaran tematik mesti mencakup kepada penilaian pengetahuan, penilaian sikap, penilaian keterampilan. Hasil dari penelitian ini diharapkan dapat memberikan rekomendasi bagi penyelanggara pendidikan dan seluruh stakeholders pendidikan agar proses pendidikan tetap bisa berlangsung dalam kondisi apapun.

\section{KESIMPULAN}

Berdasarkan hal-hal yang sudah dipaparkan dapat dikonstruksi kesimpulan penelitian yaitu keterlaksanaan pembelajaran tematik tidak dapat dilakukan secara ideal seperti saat situasi normal/ sebelum pandemi Covid-19 terjadi. Pembelajaran lebih banyak dilaksanakan secara terpisah (separated) dan bukan terintegrasi antar mata pelajaran seperti seharusnya pembelajaran tematik integratif dilaksanakan. Sementara itu dari 4 kompetensi siswa yang seharusnya menjadi capaian pembelajaran pada pembelajaran tematik kompetensi yang dapat dilaksanakan dan tercapai maksimal adalah kompetensi pengetahuan.

\section{DAFTAR PUSTAKA}

Ananda, R. (2014). Analisis Implementasi Pendekatan Saintifik dalam Pembelajaran Pendidikan Kewarganegaraan: Studi Kasus di Kelas IV SD Islam Ibnu Sina Kabupaten Bandung dan Kelas III SD Laboratorium UPI Cibiru. Universitas Pendidikan Indonesia.

Ananda, R., \& Fadhilaturrahmi, F. (2018). Analisis Kemampuan Guru Sekolah Dasar dalam Implementasi Pembelajaran Tematik di SD. Jurnal Basicedu, 2(2), 11-21.

Bogdan, B.C. and Biklen, S.K. (1982) Qualitative Research for Education, an Introduction to Theory and 
1694 Dampak Pandemi COVID-19 terhadap Pembelajaran Tematik di Sekolah Dasar-Rizki Ananda, Fadhilaturrahmi, Imam Hanafi

DOI: https://doi.org/10.31004/basicedu.v5i3.1190

Methode. Boston: Allyn and Bacon, Inc

Creswell, J.W. (2010). Research Design Qualitative, Quantitative and Mixed Methods Approach (Third Edition). Penerjemah Achmad Farwaid. Yogyakarta: Pustaka Pelajar.

Firman, F., \& Rahayu, S. (2020). Pembelajaran Online di Tengah Pandemi Covid-19. Indonesian Journal of Educational Science (IJES), 2(2), 81-89. https://doi.org/10.31605/ijes.v2i2.659

Goldschmidt, K. (2020). The COVID-19 Pandemic: Technology Use to Support the Wellbeing of Children. Journal of Pediatric Nursing.

Greenstein, L. (2012). Assessing 21 st Century skills: A guide to evaluating mastery and authentic learning. Thousand Oaks, CA: Corwin. "Guru http://krjogja.com/web/news/read/59981/Guru_Era_4_0, diakses 29 April 2019.“ Guru PAUD Harus Lulus Sarjana Pendidikan”,http://www.koranjakarta.com/gurupaud-haruslulusan-sarjana-pendidikan/, diakses 2 Mei 2019

Hussin, A. A. (2018). Education 4.9 Made Simple: Ideas For Teaching. International Journal of Education \& Literacy Studies, 6(3), 92-98.

Jamaluddin, D., Ratnasih, T., Gunawan, H., \& Paujiah, E. (2020). Pembelajaran Daring Masa Pandemik Covid19 Pada Calon Guru: Hambatan, Solusi dan Proyeksi. Karya Tulis Ilmiah UIN Sunan Gunung Djjati Bandung, 1-10. http://digilib.uinsgd.ac.id/30518/

Kemendikbud. (2020). Dampak Covid-19 Bagi Pendidikan. Jakarta: Kemendikbud

Luthfi, M. (2013). Pola Hubungan Pertumbuhan Ekonomi Dan Pembangunan Manusia Di Provinsi Jawa Timur Tahun 2007- 2011. Jurnal Bumi Indonesia. Universitas Gadjah Mada. Vol.2, No.3. Yogyakarta.

Miles, M.B., and Huberman, A.M., (1987). Qualitative Data Analysis: A Sourcebook of New Methods, Newbury Park: Sage Publication.

Mulyasa. (2013). Pengembangan dan Implementasi Kurikulum 2013. Bandung: Rosda.

Pangondian, R. A., Paulus, S. I., \& Nugroho, E. (2019). Faktor - Faktor Yang Mempengaruhi Kesuksesan Pembelajaran Daring Dalam Revolusi Industri 4.0. Seminar Nasional Teknologi Komputer \& Sains (SAINTEKS), 56-60. https://seminar-id.com/semnas-sainteks2019.html

Prastowo, A. (2014). Pemenuhan Kebutuhan Psikologis Peserta Didik SD/MI melalui Pembelajaran TematikTerpadu. JPSD: Jurnal Pendidikan Sekolah Dasar, Volume 1, Nomor 1, Agustus 2014.

Sutikno, M.S (2011). Belajar dan pembelajaran "Upaya Kreatif dalam Mewujudkan. Pembelajaran yang Berhasil”. Cetakan ketujuh, Bandung: Prospect.

Trianto. (2012). Mengembangkan Model Pembelajaran Tematik. Jakarta: PT Prestasi Pustakaraya.

Wildan, W. (2017). Pelaksanaan Penilaian Autentik Aspek Pengetahuan, Sikap dan Keterampilan di Sekolah Atau Madrasah. Jurnal Tatsqif, 15(2), 131-153. https://doi.org/10.20414/jtq.v15i2.3 